\title{
Members Rate MRS Services High, Surveys Show
}

The Materials Research Society recently undertook its first membership surveys to gain a sense of the importance members place on various aspects of MRS activities and to obtain baseline data for planning future MRS projects. Two separate but similar questionnaires were distributed to all MRS members in the fall of 1989 and to first-time members in 1990.

The results of these surveys indicate a highly positive member perception of MRS meetings and publications as a whole, but suggest the need for improvement in some areas. The results also confirm that most MRS members join the Society through MRS meeting attendance and that conference programming will, therefore, continue to play a major role in maintaining the growth of the Society.

The general membership survey, distributed in October and December of 1989 to all 9,200 MRS members, drew 1,981 responses-a $22 \%$ return rate. The newmember survey, distributed last August to 3,650 first-year members, drew 710 responses or a $19 \%$ return rate (i.e., $7 \%$ of the total 1990 MRS membership of 10,438).

Although the first survey attempted to gauge overall member opinion and the second one polled an important subset of the MRS membership, a number of survey questions were essentially the same, and the results pointed to similar conclusions.

\section{How Members Join MRS}

More than $58 \%$ of the respondents to the full membership survey reported that they joined MRS through meeting attendance, with more than $66 \%$ of the first-timers reporting likewise. The results clearly show that the MRS policy of granting complimentary membership to meeting registrants is the major factor in building MRS membership. Although $14 \%$ of members in the full membership survey and $18 \%$ in the new member survey joined the Society in response to direct mail promotions (with similar numbers joining at the suggestion of a colleague), the Society's most successful membership-building strategy has been and continues to be through meeting programming.

\section{MRS Publications}

Both survey groups responded quite favorably to the question, "Are you satisfied overall with the scope of MRS publications?" In each survey, the positive response was better than $86 \%$. The MRS Bulletin fared even better in member perception, with $87 \%$ of the full survey respondents and $91 \%$ of the first-time members reporting that they usually find something worth reading in each issue. In the 1989 survey, $94 \%$ of the respondents also said that the Bulletin has the "right technical level" and $82 \%$ said it is "useful for students."

Joumal of Materials Research is held in high esteem by MRS members, but it still has room to grow. Of the respondents to the full-membership survey, $45 \%$ said they would submit their "most important research" to JMR for publication, as did $60 \%$ of the new-member survey respondents. In the 1989 full-membership survey, the primary reason offered for not submitting research to JMR was that its topical coverage was not broad enough in particular areas, such as polymers.

It is interesting to note that $45 \%$ of the full-membership survey respondents and a full $60 \%$ of the new-member respondents said that they would submit their "most important research" for publication in $J M R$. Further study is needed to determine whether the growth in JMR's editorial content and activity during the time between these surveys, differences in demographics, or other factors resulted in the apparent gap between the two survey groups.

\section{More Active Public Role for MRS?}

Results of the full-membership survey suggest that members would like to see the Society assume a more visible role in the scientific community and in education. Nearly $77 \%$ of the members said they would like to see MRS become more active in multisociety organizations addressing multiple topics, such as the American Institute of Physics, the American Institute of Mechanical Engineers, and the Federation of Materials Societies. Additionally, $84 \%$ said they would like MRS to take a more active role in representing materials research issues to government agencies. A lower percentage of the full-survey respondents-62\%-would like MRS to become more involved in high school and undergraduate education.

\section{Members' View of Benefits}

Among the other subjects addressed in the surveys were the current and potential benefits of MRS membership. For example, first-time members were invited to rank current benefits from "least important" to "most important." Tabulation of these data is not yet complete, but some general trends are apparent: Receiving advance meeting information (calls for papers and preliminary programs) and subscriptions to Joumal of Materials Research and the MRS Bulletin ranked highest in importance with most respondents. Publications discounts, the membership directory, and discounts on meetings and short course registrations tended to be regarded as of "average" importance. Interestingly enough, voting rights in MRS elections tended to be ranked as the least important of all the current benefits.

The subject of job placement services at MRS meetings was the only instance where the two surveys appeared to be significantly at odds. Among full-survey respondents, $60 \%$ described job placement as an important membership benefit, with $17 \%$ disagreeing and $23 \%$ not responding. This benefit, at first glance, appears to have been less important to the firsttimers, who tended to rank it only above voting privileges. This discrepancy may be due, at least partly, to the difference in survey methodologies: The full-member survey asked merely whether job placement was important, while the first-timers were asked to rank it with other benefits.

A majority of respondents to the fullmember survey said, by a $51 \%$ to $44 \%$ margin, that they do not wish to see MRS institute an electronic bulletin board or newsline.

A smaller group-46\%-said that a wider program of MRS awards is not necessary, while $40 \%$ were in favor of more awards. However, among the same group $50 \%$ said "yes" when asked whether MRS should institute "fellowship" as a grade of membership to recognize outstanding members; $37 \%$ said "no"; and a resounding majority of the full-member survey respondents $-78 \%$-rejected the idea of offering group life insurance, health insurance, and MRS credit cards as new benefits.

\section{Conclusion}

Although these two surveys-the first MRS has attempted-differ in design and population, they indicate the strength of some current MRS activities and member services. From the point of view of the MRS Membership Committee, they have also provided a useful learning experience. The Committee will undoubtedly continue to sample the membership, refining the methodology and eliminating ambiguities in these surveys. The goal will be to continue to develop an accurate profile of the views and priorities of the MRS Membership.

Lynn A. Boatner David B. Sours 
Place your order now for proceedings from the 1991 MRS Spring Meeting in Anaheim and you'll receive your books as soon as they are published. The special pre-publication prices listed are effective until July 1, 1991 only. After that, please call MRS at (412) 367-3012; FAX: (412) 367.4373 for prices.

To order: contact the Materials Research Society, 9800 McKnight Road, Pittsburgh, PA 15237 U.S.A.; phone (412) 367.3012; FAX (412) 367.4373. In Europe, Africa or the Middle East, order from: Clarke-Associates-Europe, Ltd., 13a Small Street, Bristol BS1 1DE, England, phone: 0272 268864; FAX: 0272226437

Amorphous Silicon Technology - 1991

Editors: A. Madan, Y. Hamakawa, M. Thompson,

P.C. Taylor, P.G. LeComber

ISBN 1.55899.113.1 Code: $219 \mathrm{~B}$

Special pre-publication prices:

$\$ 48.00$ MRS Members

$\$ 57.00$ U.S. List $\$ 64.00$ Foreign

Silicon Molecular Beam Epitaxy

Editors: J.C. Bean, E.H.C. Parker, S. lyer,

Y. Shiraki, E. Kasper, K. Wang

ISBN 1.55899.114.X Code: $220 \mathrm{~B}$

Special pre-publication prices:

$\$ 43.00$ MRS Members

$\$ 52.00$ U.S. List $\$ 59.00$ Foreign

Heteroepitaxy of Dissimilar Materials

Editors: J.P. Harbison, A. Zangwill,

R.F.C. Farrow, P.S. Peercy

ISBN 1.55899.115.8 Code: 221B

Special pre-publication prices:

$\$ 48.00$ MRS Members

$\$ 56.00$ U.S. List $\$ 63.00$ Foreign

Atomic Layer Growth and Processing

Editors: T.F. Kuech, P.D. Dapkus, Y. Aoyagi

ISBN 1.55899-116-6 Code: 222B

Special pre-publication prices:

$\$ 43.00$ MRS Members

$\$ 52.00$ U.S. List $\$ 59.00$ Foreign

Low Energy lon Beam and Plasma

Modification of Materials

Editors: J.M.E. Harper, K. Miyake, J.R. McNeil,

S.M. Gorbatkin

ISBN 1-55899.117.4 Code: 223B

Special pre-publication prices:

$\$ 43.00$ MRS Members

$\$ 49.00$ U.S. List $\$ 56.00$ Foreign
Rapid Thermal and Integrated Processing Editors: M.L. Green, J.C. Gelpey, J. Wortman,

R. Singh

ISBN 1-55899-118-2 Code: 224B

Special pre-publication prices:

$\$ 45.00$ MRS Members

$\$ 53.00$ U.S. List $\$ 60.00$ Foreign

Materials Reliability Issues in Microelectronics

Editors: J.R. Lloyd, P.S. Ho, C.T. Sah, F. Yost

ISBN 1.55899-119-0 Code: 225B

Special pre-publication prices:

$\$ 40.00$ MRS Members

$\$ 47.00$ U.S. List $\$ 54.00$ Foreign

Mechanical Behavior of Materials and

Structures in Microelectronics

Editors: E. Suhir, R.C. Cammarata,

D.D.L. Chung

ISBN 1.55899.120.4 Code: 226B

Special pre-publication prices:

$\$ 40.00$ MRS Members

$\$ 49.00$ U.S. List $\$ 56.00$ Foreign

High Temperature Polymers for

Microelectronics

Editors: D.Y. Yoon, D.T. Grubb, I. Mita

ISBN 1.55899.121.2 Code: 227B

Special pre-publication prices:

$\$ 43.00$ MRS Members

$\$ 52.00$ U.S. List $\$ 59.00$ Foreign

Materials for Optical Information Processing

Editors: C. Warde, J. Stamatoff, W. Wang

ISBN 1.55899.122.0 Code: 228B

Special pre-publication prices:

$\$ 38.00$ MRS Members

$\$ 47.00$ U.S. List $\$ 54.00$ Foreign

Structure/Property Relationships for

Metal/Metal Interfaces

Editors: A.D. Romig, D.E. Fowler, P.D. Bristowe

ISBN 1.55899-123.9 Code: 229B

Special pre-publication prices:

$\$ 43.00$ MRS Members

$\$ 52.00$ U.S. List $\$ 59.00$ Foreign
Phase Transformation Kinetics in Thin Films Editors: M. Chen, M. Thompson, R. Schwarz,

$M$. Libera

ISBN 1.55899-124-7 Code: 230B

Special pre-publication prices:

$\$ 35.00$ MRS Members

$\$ 42.00$ U.S. List $\$ 49.00$ Foreign

Magnetic Thin Films, Multilayers and Surfaces Editor: S.S.P. Parkin

ISBN 1-55899-125-5 Code: 231B

Special pre-publication prices:

$\$ 40.00$ MRS Members

$\$ 47.00$ U.S. List $\$ 54.00$ Foreign

Magnetic Materials: Microstructure and

Properties

Editors: T. Suzuki, Y. Sugita,

B.M. Clemens, D.E. Laughlin, K. Ouchi

ISBN 1.55899.126.3 Code: 232B

Special pre-publication prices:

$\$ 40.00$ MRS Members

$\$ 47.00$ U.S. List $\$ 54.00$ Foreign

Synthesis/Characterization and Novel Applications of Molecular Sieve Materials

Editor: V.A. Mároni

ISBN 1.55899.127.1 Code: 2338

Special pre-publication prices:

$\$ 40.00$ MRS Members

$\$ 47.00$ U.S. List $\$ 54.00$ Foreign

Modern Perspectives on Thermoelectrics and Related Materials

Editors: D.D. Allred, G. Slack, C. Vining

ISBN 1-55899-128.X Code: 234B

Special pre-publication prices:

$\$ 42.00$ MRS Members

$\$ 52.00$ U.S. List $\$ 59.00$ Foreign

\section{For your convenience, a publications order form is on the back of this page.}




\section{MRS MRS \\ MATERIALS \\ RESEARCH SOCIETY}

Send this form with payment to Materials Research Society, Publications Department, 9800 McKnight Road, Pittsburgh,

Pennsylvania 15237; telephone (412) 367-3012; fax (412) 367-4373.

In EUROPE, AFRICA and the MIDDLE EAST, please order through Clarke Associates-Europe Ltd., 13a Small Street, Bristol BS1 1DE, England; telephone: 0272 268864; fax: 0272226437.

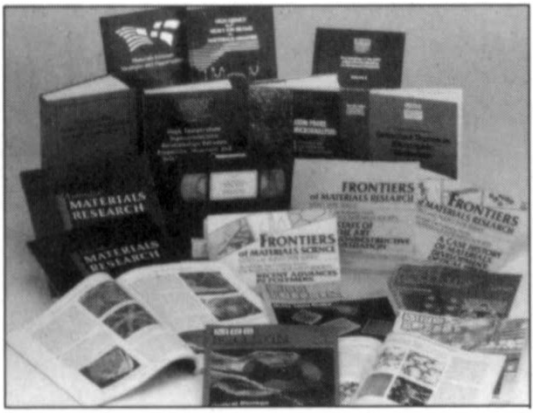

$\square$ Please send me the latest MRS Publications Catalog.

$\square$ Please send me information about the MRS

Standing Order Plan.

\begin{tabular}{|c|c|c|c|}
\hline Volume & Quantity & Price & Total \\
\hline & & $\$$ & $\$$ \\
\hline & & $\$$ & $\$$ \\
\hline & & $\$$ & $\$$ \\
\hline & & $\$$ & $\$$ \\
\hline \multicolumn{3}{|c|}{ Book \& Tape Subtotal } & $\$$ \\
\hline \multicolumn{3}{|c|}{$6 \%$ Sales Tax (PA residents only) } & $\$$ \\
\hline \multicolumn{3}{|c|}{ *Optional UPS Fee } & $\$$ \\
\hline \multicolumn{3}{|c|}{ JMR Subscriptions (from below) } & $\$$ \\
\hline \multicolumn{3}{|c|}{ MRS Bulletin Subscriptions (from below) } & $\$$ \\
\hline \multicolumn{3}{|c|}{ TOTAL DUE MRS } & $\$$ \\
\hline
\end{tabular}

\begin{abstract}
"Book prices include 4th class shipping and handling. UPS Ground Service optional in U.S.A.-add $\$ 3.00$ per book. Tape prices include UPS Ground Service in the U.S.A. and air freight elsewhere.
\end{abstract}

When ordering books in microfiche format, mark " $F$ " after the title.

\title{
BILLING AND SHIPPING INFORMATION
}

\begin{tabular}{l} 
Name__ \\
Title__ \\
Institution/Company_ \\
Address__ \\
\hline City_ State/Province_ \\
Country_ Zip/Postal Code_ Fax \\
Telephone_ \\
\\
\end{tabular}

[] Check/money order (U.S. Dollars)

Make check payable to: Materials Research Society

$\square$ Bill Company-PO\#

$\square$ Master Card $\square$ Visa $\square$ Diners Club

Card \#

Exp. Date

Signature

\section{Return Policy:}

MRS will be responsible for replacements due to shipping errors or manufacturing flaws only. No other returns accepted.

\section{MRS Journals \\ Recommendation Form}

Attention:

Librarian/Department Head

I would like to recommend subscribing to:

$\square$ Journal of Materials Research

$\square$ the MRS Bulletin

Signature

Department

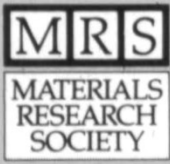

Materials Research Society

9800 McKnight Road

Pittsburgh, PA 15237

Telephone: (412) 367-3003

FAX: (412) $367-4373$
Journal of Materials Research (JMR)

Official archival journal of the Materials Research Society. (In Japan, order JMR from Kinokuniya Company Ltd., Journal Department, P.O. Box 55 Chitose, Tokyo 156, Japan.)

$\square$ Enter my subscription to Journal of Materials Research

1991 rates for 12 issues (check below and enter amount in order chart above):

$$
\square \$ 285 \text { U.S.A. } \square \$ 305 \text { Elsewhere }
$$

$\square$ Please send information on back issues of JMR.

$\square$ Please send me a complimentary copy of JMR.

\section{MRS Bulletin}

Interdisciplinary coverage of the latest news, policy, products and events of interest to materials researchers. Technical review articles offering broad overviews of important research fields.

$\square$ Enter my subscription to MRS Bulletin.

1991 rates for 12 issues (check below and enter amount in order chart above):

$$
\square \text { \$88 U.S.A. } \square \text { \$128 Elsewhere }
$$

$\square$ Please send information on back issues of the MRS Bulletin.

$\square$ Please send me a complimentary copy of the MRS Bulletin 


\section{EQUIPMENT EXHIBIT \\ 1991 MRS Spring Meeting \\ Anaheim Convention Center \\ Tuesday-Thursday, April 30 - May 2, 1991}

As part of the 1991 Spring Meeting, a major equipment exhibit will display analytical and processing equipment closely paralleling the nature of the technical symposia. The exhibit will be in the Anaheim Convention Center, and the technical program has been arranged to allow meeting participants ample opportunity to visit the exhibit.

\begin{tabular}{|c|} 
Show Hours \\
Tuesday ............................... noon - 7:00 p.m. \\
Reception .......................50 p.m. - 7:00 p.m. \\
Wednesday .......................9:30 a.m. - 5:00 p.m. \\
Thursday ...........................9:30 a.m. - 2:00 p.m.
\end{tabular}

\section{MRS SPRING SHOW EXHIBITORS AS OF FEBRUARY 6, 1991}

Academic Press, Inc.

AET addax

AG Associates

Aixtron $\mathrm{GmbH}$

American Institute of Physics

Anatech Lid.

APD Cryogenics

Applied Science and

Technology, Inc. (ASTeX)

Atom Tech, Inc.

Axic Inc.

Cahn Instruments

Cambridge Molecular Design

Commonwealth Scientific

Cookson Plasmaterials

Cryomech Inc.

CVC Products, Inc.

Denton Vacuum, Inc.

Diatome US

Duniway Stockroom Corp.

Elsevier Science Pub. Co.

EMCORE Corporation

EPI

Charles Evans \& Assoc.

Extrel FTMS

E. A. Fischione Instruments, Inc.

Flexus Inc.

Gatan

GMW Associates
Granville-Phillips Co.

High Vacuum Apparatus Mifg.

High Voltage Engineering Europa B.V.

Hologenix Inc.

Huntington Mechanical Labs

Intemational Scientific Instruments

Ion Tech, Inc.

Janis Research Company

JEOL U.S.A., Inc.

Keithley Instruments

Kevex/Fisons Instruments

Kratos Analytical

Lake Shore Cryotronics

Lasertec U.S.A., Inc.

Kurt J. Lesker Co.

Link Analytical

Luxtron Corporation, Accuriber Division

MDC Vacuum Products Corporation

MKS Instruments

MMR Technologies

Morris Research, Inc.

National Electrostatics Corp.

NESLAB Instruments Inc.

NGS Associates, Inc.

NOR-CAL Products, Inc.
Nordiko USA, Inc.

North Eastem Analytical

Oxford Applied Research

Oxford Instruments N.A.

Oxford Plasma Technology

Peak Systems, Inc.

Pergamon Press

Perkin-Elmer Corp.

Philips Electronic Instruments

Plasma Sciences, Inc.

Princeton Gamma-Tech

Princeton Research

Instruments, Inc.

Quantum Design, Inc.

Research Inc.

Rocky Mountain Laboratories, Inc.

S T A I B Instrumente

South Bay Technology, Inc.

Structure Probe, Inc/SPI Supplies

Superior Vacuum Technology

Surface/Interface, Inc.

Tamarack Scientific Co., Inc.

VG Instruments/Fisons Instruments

Voltaix, Inc.

XMR 